\title{
Paediatric origins of adult lung disease
}

\section{Introduction}

Peter D Sly

Managing lung diseases makes up a large part of the daily work of general practitioners, paediatricians, specialists in internal medicine, and respiratory physicians. While the spectrum of diseases managed by these different groups may differ, many of the diseases are likely to have common origins and are influenced by early life events. The fetal origins of disease have been recognised recently in the relationships between birth weight and cardiovascular disease in adults in the UK and have led to the so-called Barker hypothesis. ${ }^{1}$ This initial report has led to a growing interest in determining how early life events can influence the expression of disease later in life. This is particularly true for lung diseases with a growing recognition of the influences of the intrauterine environment on lung growth and development. The most well known example of this has been the effects of maternal smoking on lung growth. ${ }^{2-5}$ However, the influences of other environmental factors such as premature birth, ${ }^{6-8}$ maternal diet, and allergen exposure on subsequent respiratory disease are attracting increasing attention..$^{9-12}$

Respiratory infections are common during the first few years of life and the vast majority are mild. However, there is a growing recognition that viral infections in early life, even mild infections, may be associated with long term sequelae. ${ }^{1314}$ Recurrent wheezing following severe acute viral bronchiolitis requiring admission to hospital is well recognised, but the effects of less severe viral lower respiratory infections have not been recognised until recently. ${ }^{15}$ There is currently confusion in the literature as to whether respiratory infections early in life promote or protect against the development of asthma later. ${ }^{16-18}$ This is partly due to the failure to distinguish adequately between site of infection (upper respiratory versus lower respiratory), causative agent (whether the respiratory syncytial virus produces a different pattern of long term sequelae from other viruses), and the clinical phenotype (transient infantile wheeze versus atopic asthma). An understanding of the true relationships between respiratory infections in early life and lung diseases in adult life will allow a better understanding of the disease mechanisms underlying some adult lung diseases.

The pattern of respiratory diseases managed by the adult respiratory physician is changing. With increasing survival of children with cystic fibrosis, the development of cystic fibrosis clinics in adult hospitals has become necessary. Mechanical ventilation was introduced to increase the survival of infants born prematurely a little over 30 years ago. Since that time major advances have occurred in neonatal intensive care and in mechanical ventilation such that infants born as early as 22 weeks gestation are routinely treated in many neonatal units and many survive. Northway originally described the radiological appearance of a chronic lung disease of prematurity, which he called bronchopulmonary dysplasia, in $1967 .{ }^{19}$ This was thought to be the consequence of mechanical ventilation and hyperoxia on the lungs. Since the original description the pattern of disease has changed. With the survival of infants who are in the early phases of alveolar development, the type of lung injury seen with mechanical ventilation and hyperoxia in these infants has changed. ${ }^{20}$ While we do not know with certainty what problems these children may have in adult life, one would predict that they may have increased respiratory problems as their lung function undergoes the decline associated with aging.

In order to highlight some of the issues that may confront adult respiratory physicians in the future, a series on the paediatric origins of adult lung diseases has been compiled. A series of articles, edited by Stephen Stick and myself, will be presented in coming issues of Thorax. The series consists of two parts. In the first part general developmental issues will be covered to set the scene for more specific, disease orientated, articles in the second part. The first article by Stephen Stick entitled "The contribution of airway development to paediatric and adult lung diseases" highlights the differing influence of adverse insults depending on the timing of the insult. The second article entitled "Prevention of asthma and atopic diseases in adults begins in childhood" by Patrick Holt and Peter Sly reviews developmental aspects of primary allergic sensitisation and how this may translate into atopic disease. The third article on "The genesis of adult sleep apnoea in childhood" by Francis McNamara and Colin Sullivan outlines how developmental factors play an important part in this most adult of adult respiratory diseases. Finally, Peter Le Souef discusses how "Tobacco related lung diseases begin in childhood", especially in relation to initiating the addiction to nicotine which is central to the problem we face with smoking. 
The second part will focus on the adult consequences of specific paediatric lung diseases. Max Zach and Ernst Eber review the effects of congenital lung diseases, Erika von Mutius clarifies the relationship between wheezing illnesses and asthma in childhood and adult lung function and asthma, Philip Robinson reports how cystic fibrosis is becoming more of a problem to adult physicians, and Ernst Eber introduces chronic neonatal lung disease to a new audience and shows how this may become the adult chronic obstructive lung disease of the future.

Having read the articles published in this series, adult physicians should have a greater awareness of the issues currently facing paediatric pulmonologists and of how these issues are likely to impact on the practice of adult respiratory medicine in the near future.

1 Barker DJ, Godfrey KM, Fall C, et al. Relation of birth weight and childhood respiratory infection to adult lung function and death from chronic obstructive airways function and death from chro.

2 Hanrahan JP, Tager IB, Segal MR, et al. The effect of maternal smoking during pregnancy on early infant lung function. Am Rev Respir Dis 1992;145:1129-35.

3 Tager IB, Ngo L, Hanrahan JP. Maternal smoking during pregnancy. Effects on lung function during the first 18 months of life. Am $\mathcal{F}$ Respir Crit Care Med 1995;152:97783.

4 Stick S, Burton P, Gurrin L, et al. Effects of maternal smoking during pregnancy and a family history of asthma on respiratory function in newborn infants. Lancet 1996;348: 1060-4.

5 Hoo AF, Henschen M, Dezateux C, et al. Respiratory function among preterm infants whose mothers smoked during pregnancy (see comments). Am 7 Respir Crit Care Med 1998;158:700-5.
6 Coalson JJ, Winter VT, Siler-Khodr T, et al. Neonatal chronic lung disease in extremely immature baboons. Am $\mathcal{f}$ chronic lung disease in extremely immature

7 Kitchen WH, Rickards AL, Doyle LW, et al. Improvement in outcome for very low birthweight children: apparent or real? Med f Aust 1992;157:154-8.

8 Smyth JA, Tabachnik E, Duncan WJ, et al. Pulmonary function and bronchial hyperreactivity in long-term survivors of bronchopulmonary dysplasia. Pediatrics 1981;68:336-40.

9 Langley-Evans SC, Phillips GJ, Jackson AA. Fetal exposure to low protein maternal diet alters the susceptibility of young adult rats to sulfur dioxide-induced lung injury. $\mathcal{F}$ young adult rats to sulf

10 Langley-Evans SC, Seakins M, Grimble RF, et al. The acute phase response of adult rats is altered by in utero exposure to maternal low protein diets. F Nutr 1994;124:1588-96.

11 Warner JA, Jones CA, Williams TJ, et al. Maternal programming in asthma and allergy. Clin Exp Allergy 1998;28(Suppl 5):35-8, 50-1.

12 Warner JA. Primary sensitization in infants. Ann Allergy Asthma Immunol 1999;83:426-30.

13 Henderson FW, Stewart PW, Burchinal MR, et al. Respiratory allergy and the relationship between early childhood lower respiratory illness and subsequent lung function. $\mathrm{Am}$ Rev Respir Dis 1992;145:283-90.

14 Rev Respir Dis 1992;145:283-90. atopic disorder. Thorax 1998;53:927-32.

15 Stein RT, Sherrill D, Morgan WJ, et al. Respiratory syncytial virus in early life and risk of wheeze and allergy by age 13 years (see comments). Lancet 1999;354:541-5.

16 Folkerts G, Busse W, Nijkamp F, et al. Virus-induced airway hyperresponsiveness and asthma. Am $\mathcal{F}$ Respir Crit Care Med 1998;157:1708-20.

17 de Jongste JC, Brunekreef B. On eggs and chicken (editorial; comment). Eur Respir 7 1999;14:2-3.

18 Martinez FD, Stern DA, Wright AL, et al. Differential immune responses to acute lower respiratory illness in early life and subsequent development of persistent wheezing and asthma. F Allergy Clin Immunol 1998;102:915-20.

19 Northway WH Jr, Rosan RC, Porter DY. Pulmonary disease following respirator therapy of hyaline-membrane disease. Bronchopulmonary dysplasia. N Engl f Med 1967;276: $357-68$.

20 Edwards DK. The radiology of bronchopulmonary dysplasia: the pulmonary pathologic sequel of necrotizing bronchiolitis and pulmonary fibrosis. In: Merritt TA, Northway WHJ, Boynton BR, eds. Bronchopulmonary dysplasia. Boston: Blackwell Scientific, 1988: 185-234. 